\author{
Ye.I. Barabanova ${ }^{1}$, G.Z. Adilgazinov², A.T. Zhakupov ${ }^{3}$ \\ ${ }^{1}$ S. Amanzholov East Kazakhstan State University, Ust-Kamenogorsk, Kazakhstan; \\ ${ }^{2}$ University «Turan-Astana», Nur-Sultan, Kazakhstan; \\ ${ }^{3}$ "Qazproftec» LLP, Nur-Sultan, Kazakhstan \\ (E-mail:anb777@yandex.ru,gainelgazy@mail.ru,qazproftec@gmail.com)
}

\title{
Features of the professional development of students with special educational needs under the condition of an inclusive college
}

\begin{abstract}
The article presents the results of a comparative study of the professional development of two professional-technical inclusive colleges students in the East Kazakhstan oblast. The study engaged 50 students with special educational needs (hereinafter, SEN). The methodological basis of the study was the author's psychodiagnostical development of career-oriented websites of Kazakhstan scientists, presented on the career-oriented website Bagdar.kz.Based on the data analysis, conclusions are drawn about the discrepancy between the inclinations and interests of students to the real choice of studying in the specialty. The results of the selection of students with SEN in 12 professional sectors and 36 specialties were considered. The leading motives and needs in the choice of professional orientation are determined, which are correlated with the choice of specialty of students with SEN from VET. The attractive types of activities, objects of labor and preferred means of labor for students with SEN of inclusive colleges are identified. The practical implication of the study lies in a detailed examination of the professional intentions and interests of students with special educational needs at the stage of professional development under conditions of a college. The practical value of the study is determined by the fact that it is focused on solving problems associated with the individualization of vocational training and providing assistance to every student with SEN who needs it and experiences difficulties in the course of professionalization.
\end{abstract}

Keywords: inclusive training, people with disabilities, inclusion, inclusive education, college.

\section{Introduction}

Changing the socio-political structure of the Republic of Kazakhstan, carrying out activities aimed at democratization of society in accordance with international legal documents of the United Nations has contributed to the formation of a new position on the attitude of the state and society towards persons with disabilities, including the education of children.

Nowadays the principle of priority of the interests of the individual over the interests of society through guaranteed observance of the rights and freedoms of everyoneis proclaimedin Kazakhstan. The attitude to persons with disabilities is based on the idea of social rehabilitation, which involves the achievement of maximum self-sufficiency and independence in society by persons with disabilities.

The right to education is the right of everyone. And the education of children is the main and indispensable condition for their socialization, full participation in society. That is why, within the framework of the education development program for 2011-2020, the gradual development of inclusive education is provided in Kazakhstan, so that children with disabilities really had the opportunity to study fully and receive knowledge on the same basis as the others [1]. Serious attention has been paid to this in the next State program for the development of education for 2016-2019 [2]. Social adaptation is one of the priority areas of inclusive education in Kazakhstan. Under the conditions of modernization of Kazakhstan education, the development of adaptive strategies mechanisms for children with special educational needs is a logical step related to the rethinking by society and the state of their attitude towards people with special educational needs.

Immediacy of the problems of inclusive education is increasing due to an increase in the number of children with special educational needs and in connection with the humanization of education, which dictates the need for providing conditions for improving the quality of life of people with disabilities, increasing their viability as a product of social interaction, and involvement of a person in social networks.

Our society is not yet ready for the mass introduction of inclusive education in the system of general, technical and professional higher education, since both the regulatory and substantive aspects of special children teaching are not well developed, their rights to receive qualification education are not defined. 
The works of H.S. Eralieva, D.D. Eshpanova, D.S. Zhakupova, A.K. Zhalmukhamedova, Z.A. Movkebayeva, I.A. Oralkanova, Zh.I., Sardarova, N.S. Zhumasheva and others are devoted to the issues of inclusive education of students with disabilities in the Republic of Kazakhstan [3, 4].

Readiness of teachers for professional activity in the conditions of inclusive education in Kazakhstan, as well as the attitude of teachers to the introduction of inclusive education in general academic schools of Kazakhstan were the subject of study of researchers A.N. Sakaeva, Z.Ya. Oleksyuk, L.A. Shkutina, Ya. Danek, A.R. Rymkhanova and others [5, 6].

In scientific terms, the need to address this problem is caused due to the lack of an established system of views on understanding the laws of professionalformationin psychology, the inconsistency of certain provisions in existing approaches to this problem, the need for generalization and systematization of numerous facts accumulated in various branches of psychological science, the need for further development of General psychological theory of personality.

The analysis has allowed determining that in modern society the role of the individual as a participant in the production and the organizer of his own professional life increases significantly, the price of human failings and the demand for his creative abilities increases. All this significantly increases the requirements for the personality of a professional and leads to the need for improvement of the system of continuous professional education and support of specialists at various stages of the work path.

At the same time, it should be admitted that insufficient attention is paid to the dynamics of the formation of various personality substructures at the stages of the professional path. The criteria of professionalization, indicators of the level of formation of a professional are not clearly defined, their relationship with each other and with individual substructures of personality is not studied. The professional becoming of students in the system of college and inclusive college has not been practically studied. There are no clear grounds for the periodization of professional becoming of students with special educational needs.

We have used tests in our study, that are the product of Kazakhstan developers and the authorship of which is recorded as intellectual property. The tests are presented on the portal bagdar.kz [7]. The complex of career guidance tests consisted of the following substantive tests.

1) Self-assessment of interests, inclinations and abilities in various professional spherestest. The questionnaire shows an assessment of 36 majors distributed across 12 professional branches.

2) «Dominant needs and motives in the choice of professional activity» test. It allows to determine the leading motives and needs from the following list: the need for power/control of others; search for new experiences/need for extreme activities; the need for a career/career elevation; high social involvement and the possibility of intensive communication in the work process; the need for favorable conditions of work/comfort; the need for creative and interesting work, creative self-actualization; the need to perform individual/self-guided work; the need for low tension/lack of stressors in the work; high work intensity, activity, lack of monotony and routinism; the need to educate others; the need for well regulated activities; the need for manual labor (do something with your hands).

3) «Defining a profession by type of activity» test is meant to assess the most preferred types of professional activity. Specific professional activity is characterized by the specifics of the subject, conditions, work content and requirements for it.

4) «Instruments of labor in professional activity» test is intended to assess the preferred instrument of labor in professional activity: manual instruments of labor, mechanic instruments of labor, automated instruments of labor, information technologies and instruments of computer technology, personal function capabilities of a person.

5) «Defining a profession by an object of labor» test is intended to assess the most preferred objects of labor in professional activity: person, information, finances, engineering, art, animals, plants, food products, wares, natural resources.

The research was based on two colleges - «East Kazakhstan College of Technology» Municipal State-Owned Public Enterprise of the Semey city and «Ust-Kamenogorsk College of services sector» Municipal Public Institution of East Kazakhstan Education Department.

The selection consisted of 50 students with SEN (22 students at the College in Ust-Kamenogorsk city and 28 students in Semey city). 
22 students with SEN of 33 from the college of the Ust-Kamenogorsk city took part in the study, which is $67 \%$ of this selection of students with SEN. The study involved students in the following specialties:

- 11 students (50\%)study Computer Engineering and Software qualifying in «Computer serviceman»;

- 3 students (13.6\%)study Hairdressing and decorative cosmetics qualifying in «Hair stylist»;

- 1 student (4.5\%) studies Apparel production and apparel design qualifying in «Designer-Apparel cutter»;

- 6 people $(27.2 \%)$ study Furniture production (by type) qualifying in «Master of joiner and cabinet making»;

-1 person $(4.5 \%)$ studies Tourism qualifying in «Touristic agent».

There are following data for the disablement group:5 people of group II $(22.7 \%)$ and 17 people of group of disablement III $(77.2 \%)$.

The following data according to the specifics of the diagnosis in this group:

- with ICP diagnosis - 6 people $(27.2 \%)$,

- hearing disorder, deafness - 11 people $(50 \%)$,

- epilepsy - 1 person $(4.5 \%)$,

- diabetes mellitus - 1 person $(4.5 \%)$,

- chest distortion - 1 person $(4.5 \%)$,

- legcoxarthrosis - 1 person $(4.5 \%)$,

- posttraumatic encephalopathy - 1 person $(4.5 \%)$.

The study has involved 28 SEN students of the college of the Semey city from 59 SEN students, which is $47 \%$ of this selection. Thus: man»;

- 15 people $(53,5 \%)$ study Computer Engineering and Software qualifying in «Computer service-

- 7 people (25\%) study Apparel production and apparel design qualifying in «Designer-Apparel cutter»;

-6 people $(21.4 \%)$ study «Catering service».

For the disablement group there are the following data:5 people (17.8\%) are without disability, 1 person $(3,5 \%)$ is with a disability of group I, 3 people $(10,7 \%)$ have group II and 18 people $(64,2 \%)$ have group III of disablement.

According to the specifics of the diagnosis in this group the following data are observed:

- ICP - 3 people $(10,7 \%)$;

- sensorineural hearing loss - 17 people $(60,7 \%)$;

- fibrillary-protoplasmatic astrocytoma - 1 person $(3,5 \%)$;

- organresidual encephalopathy (cerebrosthenic syndrome) - 1 person $(3,5 \%)$;

- residual organic encephalopathy -1 person $(3,5 \%)$;

- idiopathic epilepsy - 1 person $(3,5 \%)$;

- scoliosisof thoracic spine - 1 person $(3,5 \%)$;

- concomitant strabismus, exotropia - 1 person $(3,5 \%)$;

- chronic rheumatic heart disease. Complex heart defect. Mitral valve incompetence - 1 person $(3,5 \%)$,

\section{Results description}

Figure 1 presents the results of the self-esteem of interests, inclinations and abilities in various professional spheres determination test. 


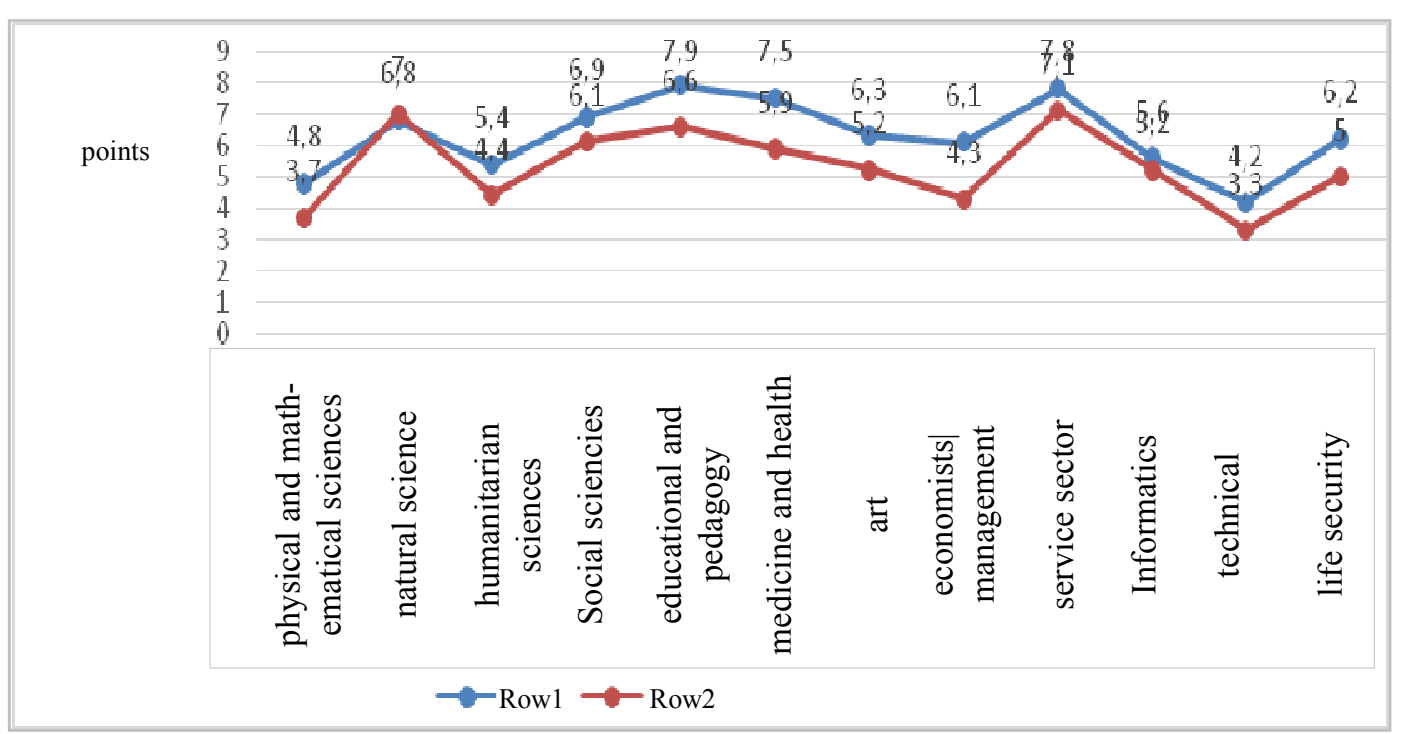

Row 1 - students with SEN from the College of Ust-Kamenogorsk city Row 2 - students with SEN from the College of Semey city

Figure 1. The results of average values for the self-esteem of interests, inclinations and abilities in various professional spheres determination test of students with SEN of two colleges.

The results of this test of 10-12 points, either in one of 36 specialties, or in the branch may be an indicator of readiness to master it and move in this direction. However, such assessments were not found in any branch or in any specialty. This may indicate that these students at the stage of training still have not formed a stable professional intention, which would characterize the presence of knowledge in this area, emotional relations and assessment of skills to perform these professional functions.

The results of 6-9 points can indicate only a pronounced tendency in the development of this specialty. In this case, the services sectors are pronounced ( 7.8 average score for college students in Ust-Kamenogorsk and 7.1 points for college students in Semey). Next are the branches related to natural sciences (6,8 and 7 points), education and educational science (7,9 and 6,6 points) and social sciences $(6,9$ and 6,1$)$.In addition, students from the Ust-Kamenogorsk Collegehave shown interest in the field of medicine and health $(7,1)$, art $(6,3)$, economics/management $(6,1)$ and life safety $(6,2)$.

If we consider the predominant choice of the desired specialties, students with an SEN from a UstKamenogorsk collegeit will be: defectology $(8,3)$, sociology and social work $(7,9)$, ecology, environmental engineering and safety $(7,8)$, service, tourism and hotel business $(7,8)$,

Choice of desired specialties for students with SEN from Semey College turns to agriculture, forestry and fisheries (8), ecology, environmental engineering and safety $(7,5)$, sociology and social work $(7,2)$. The smallest values were in the specialties of technical and technological sciences (4.2 and 3.3), physical and mathematical sciences (4.8 and 3.7), and humanities (5.4 and 4.4).

Thus, we see that expressed interests and evaluations of own inclinations of students with SEN from colleges were not found. At the same time, there is a tendency in the professional orientation in the following specialties in both colleges -agriculture, forestry and fisheries, ecology, environmental engineering and safety, sociology and social work. In addition, college students from the Ust-Kamenogorsk city have a predominance of interest in the professions of the social services. We also found that, although half the selections of students, both in the college of Ust-Kamenogorsk and of the Semey, are students of the specialty computer science, however, the test results indicate unexpressed inclinations and interest in this professional area. Professions and specialties related to the exact sciences or technologies, as well as those involving philological education, are not relevant in the choice of students, which most likely indicates an objective self-assessment of these test persons.

Next, we consider the results associated with the prevailing motives and needs in the choice of specialty (Table 1). 
The results of the average values for «Dominant needs and motives in the choice of professional activity» test among students with SEN of two colleges

\begin{tabular}{|c|l|c|c|}
\hline No. & \multicolumn{1}{|c|}{ Scales } & $\begin{array}{c}\text { College of Ust- } \\
\text { Kamenogorsk }\end{array}$ & $\begin{array}{c}\text { College of } \\
\text { Semey }\end{array}$ \\
\hline 1 & The need for power/control of others & 0,6 & 0,2 \\
\hline 2 & Search for new experiences/need for extreme activities & 0,2 & 0,1 \\
\hline 3 & The need for a career/career elevation & 0,5 & 0,3 \\
\hline 4 & $\begin{array}{l}\text { High social involvement and the possibility of intensive com- } \\
\text { munication in the work process }\end{array}$ & 0,6 & 1 \\
\hline 5 & The need for favorable conditions of work/comfort & 0,5 & 0,6 \\
\hline 6 & $\begin{array}{l}\text { The need for creative and interesting work, creative self- } \\
\text { actualization }\end{array}$ & $-0,2$ & $-0,5$ \\
\hline 7 & The need to perform individual/self-guided work & $-0,2$ & $-0,6$ \\
\hline 8 & The need for low tension/lack of stressors in the work & $-0,5$ & 0,07 \\
\hline 9 & High work intensity, activity, lack of monotony and routinism & $-0,2$ & 0,5 \\
\hline 10 & The need to educate others & 2,3 & 2,2 \\
\hline 11 & The need for well regulated activities & 0,09 & 0,2 \\
\hline 12 & The need for manual labor (do something with your hands) & 0,4 & 0,6 \\
\hline
\end{tabular}

It should be noted that this test also did not show high rates in the average scores for groups, which would indicate the prevailing need for choosing a profession. At the same time, there is a slight tendency for students with SEN from two colleges to have a profession associated with the teaching of others (2.3 and 2.2 points).At the same time, for such students, the need for creative and interesting work, in creative selfrealization is not the main one (0.2 and -0.5).To individually and independently carry out work for students with SEN is also not a motive of a professional orientation $(-0.2$ and -0.6$)$.

Thus, we can say that the motivation of a professional orientation is not clearly expressed. There is some tendency to connect your profession with the service, education and teaching of others, but this also requires own development. The need to perform work in a group and a team is more significantthan the choice of professions associated with the independent performance of the functional. Professions related to inventing, creating something new, non-standard approach are also not predominatein choice, in contrast to the desire to perform more accurate and typical work on a specific cliche.

Further we consider the professional orientation depending on the choice of the type of professional activity (Fig. 2).

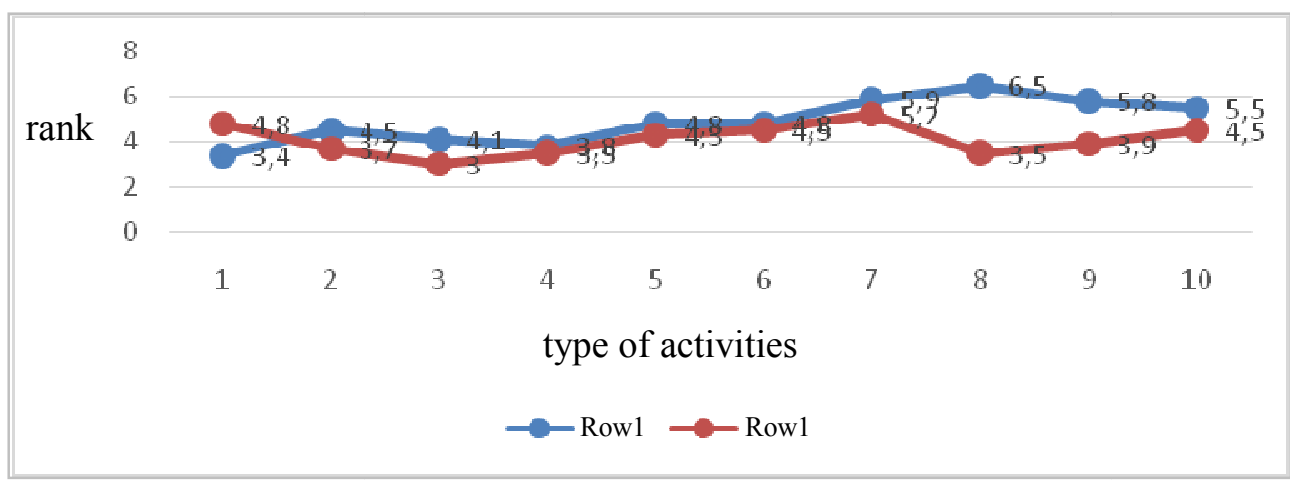

OX: typeofactivities: 1) management, 2) services, 3) education, 4) health improvement, 5) art, 6) production, 7) design, 8) research, 9) protection, 10) control OY: rank

Row 1 - students with SEN from the College of Ust-Kamenogorsk city

Row 2 - students with SEN from the College of Semey city

Figure 2. The average value of ranks on «Definition of profession by type of activity» test of students with SEN from two colleges 
Figure 2 shows that most students with SEN from the College in Ust-Kamenogorsk are attracted to activities related to the management of other people, their organization and control $(3,4 \%)$.

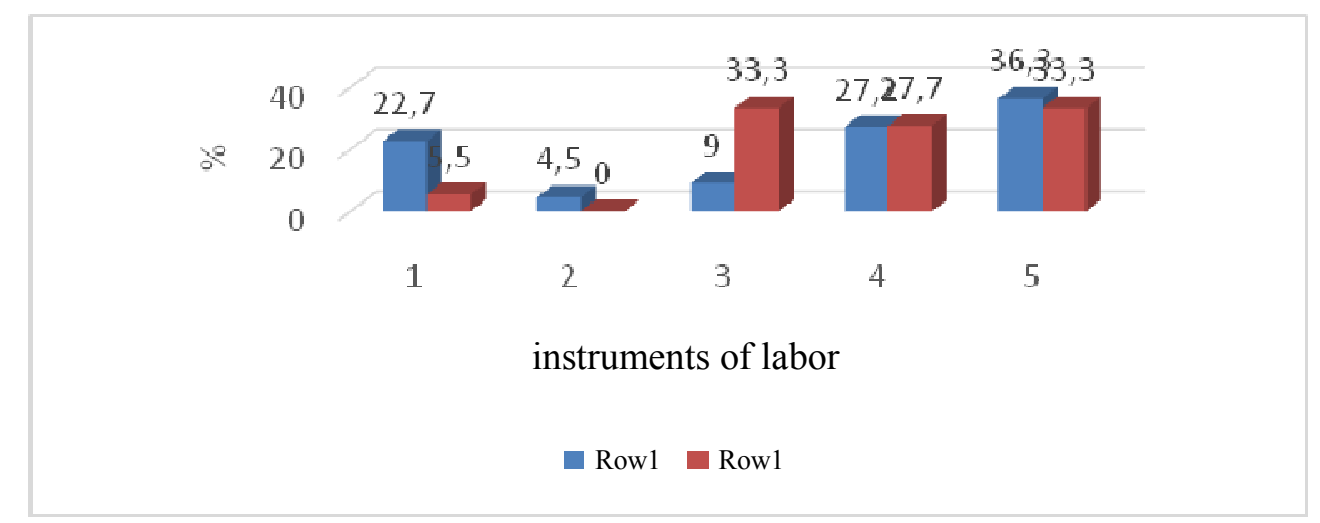

OX: instruments of labor: 1) manua linstruments of labor, 2) mechanic instruments of labor, 3) automated instruments of labor, 4) information technologies and instruments of computer technology, 5) personal function capabilities of a person, ОY:\%

Ряд 1 - students with SEN from the College of Ust-Kamenogorsk city Ряд 2 - students with SEN from the College of Semey

Figure 3. Average value of ranks on «Instruments of labor in professional activity» test of students with SEN from two colleges

For students with a SEN from a College in Semeyin selection of the type of desired activity, it is important that it is associated with education, it is interesting for them to teach, educate and engage in the development of children in various social institutions (rank 3). In two groups of test persons, types of activities related to construction were found that are not desirable in mastering the profession (5.9 and 5.2 rank).

In this regard, the design, construction of parts and objects, their testing is not an attractive activity. For students from a college of Ust-Kamenogorsk, professions related to research (6.5 ranks) and protection (5.8 ranks) are also not interesting. In this regard, to analyze, research, scientifically study anything does not attract them, as well as to protect or defend people from negative external influences associated with insecurity for citizens.

According to figure 3 it is possible to consider attractive means of work at a choice of professional activity.us, we see that for the majority of students with SEN in two colleges, the preferred instruments of work are the personal capabilities of the person (36.3\% and 33.3\%). For such testees, the use of their personal capabilities, such as thinking, behavior, speech, using little and resorting to additional means and devices, is a more attractive instrument of labor. An interesting fact is that for students with SEN from the Semey city, the instruments of labor associated with automated equipment, automatic production lines of any products is also an attractive instruments of labor (33.3\%), while for students of the other group it is represented at a low level. The use of information technology is presented as a instruments of labor in about $27 \%$ of students with SEN.

Another type of analysis will be the consideration of preferred objects of work for students with SEN from colleges (Fig. 4). 


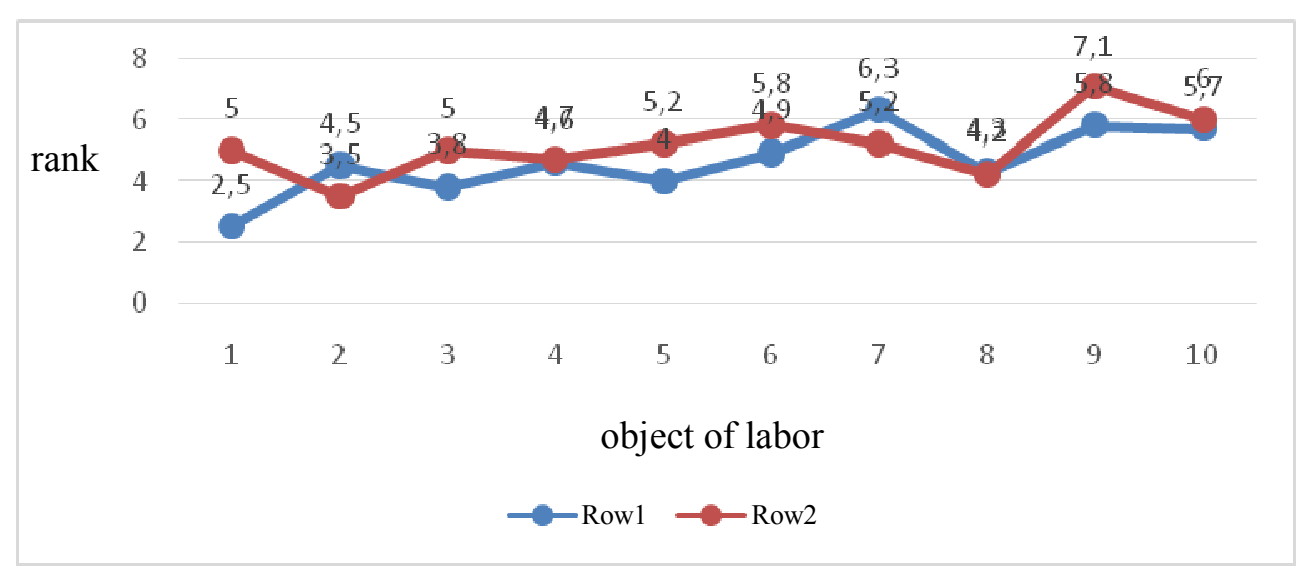

OX: objectoflabor: 1) person, 2) information, 3) finances, 4) engineering, 5) art, 6) animals, 7) plants, 8) food products, 9) wares, 10) natural resources OY: rank

Row 1 - students with SEN from the College of Ust-Kamenogorsk city; Row 2 - students with SEN from the College of Semey city

Figure 4. The average value of the ranks on «Definition a profession by the object of labor» test of students with SEN from two colleges

An analysis of preferred objects of labor allows us to state that for students with SEN from a college in Ust-Kamenogorsk the preferred object is a person ( $2.5 \mathrm{rank})$. The professions that are related to teaching, the upbringing of children, with trade or public services may be interesting for them.

Students from a college in the city of Semey have a greater degree of interest in working with information (3.5 rank).With a professional orientation, they need to focus on professions related to text, formulas, symbols.

\section{Summaries}

Generalized results on the professional orientation of college students with SEN allow us to state the following.

1) Students did not show expressed interests, inclinations and assessment of abilities, which would characterize the predominance of orientation in the professional branch or specialty.

2) There is a tendency in interest in the following specialities in both colleges - agriculture, forestry and fisheries, ecology, environmental engineering and safety, sociology and social work. In addition, college students from Ust-Kamenogorsk city have a predominance of interest in the services sector professions. We also found that, although half the selections of students, both in the college of Ust-Kamenogorsk and of the Semey, are students of the computer science specialty, however, the test results indicate unexpressed inclinations and interest in this professional area. Professions and specialties related to the exact sciences or technologies, as well as those involving philological education, are not relevant in the choice of students, which most likely indicates an objective self-assessment of these test persons.

3) Motivation of professional orientation is not clearly expressed in students with SEN in both colleges. There is some tendency to connect your profession with the service, education and teaching of others, but this also requires own development. The need to perform work in a group and a team is more signify than the choice of professions associated with the independent performance of the functional. Professions related to inventing, creating something new, non-standard approach are also not predominatein choice, in contrast to the desire to perform more accurate and typical work on a specific cliche.

4) Students with SEN from the College in Ust-Kamenogorsk are attracted to activities related to the management of other people, their organization and control. For students with a SEN from a College in Semeyin selection of the type of desired activity, it is important that it is associated with education, it is interesting for them to teach, educate and engage in the development of children in various social institutions. In two groups of testees, types of activities related to construction were found that are not desirable in mastering the profession. For students from a college of Ust-Kamenogorsk, professions related to research and protection are also not interesting. 
5) For the majority of students with SEN in two colleges, the preferred instruments of work are the personal capabilities of the person. For students with SEN from the Semey city, the instruments of labor associated with automated equipment, automatic production lines of any products is also an attractive instruments of labor.

6) For students with SEN from a college in Ust-Kamenogorsk the preferred object is a person. Students from a college in the city of Semey have a greater degree of interest in working with information.

The practical value of the study is determined by the fact that it is focused on solving problems associated with the individualization of vocational training and providing assistance to every student with SEN who needs it and experiences difficulties in the course of professionalization. In addition, the results make it possible to determine that early diagnosis of the professional choice of students with SEN can help make a more correct choice of their further professional formation, and will not be limited only to the opportunity to study at only two or three colleges in the oblast that really imply inclusive education, but will provide an opportunity to choose specialties of technical and professional education in accordance with their desires and capabilities.

This publication has been carried out as part of «Unified information system for career guidance, analysis and forecasting the needs of specialties» Subproject funded as a part of "Stimulating of Productive Innovations» Project supported by the World Bank and the Government of the Republic of Kazakhstan. Statements may not reflect the official position of the World Bank and the Government of the Republic of Kazakhstan.

\title{
References
}

1 Государственная программа развития образования Республики Казахстан на 2011-2020 годы, утв. Указом Президента Республики Казахстан от 07.12.2010 г. № 1118 // Казахстанская правда. — 2010. — № 153, 154. - С. 10-12.

2 Указ Президента Республики Казахстан от 1 марта 2016 года № 205 «Об утверждении Государственной программы развития образования и науки Республики Казахстан на 2016-2019 годы». [Электронный ресурс]. — Режим доступа: http://adilet.zan.kz

3 Ералиева Х.С. Внедрение инклюзивного образования в Казахстане / Х.С. Ералиева // Инновационные педагогические технологии: материалы IV Междунар. науч. конф. (г. Казань, май 2016 г.). — Казань: Бук, 2016. — С. 26-28.

4 Сардарова Ж.И. Инклюзивное и интегрированное обучение в Республике Казахстан / Ж.И. Сардарова, Н.С. Жумашева // Науч.-метод. электрон. журн. «Концепт». — 2017. — Т. 35. — С. 113-116.

5 Сакаева А.Н. Готовность педагогов к профессиональной деятельности в условиях инклюзивного образования / А.Н. Сакаева, 3.Я. Олексюк // Вестн. Караганд. ун-та. Сер. Педагогика. — 2016. — № 1(81). — С. 32-38.

6 Шкутина Л.А. Отдельные аспекты отношения учителей к внедрению инклюзивного образования в общеобразовательные школы / Л.А. Шкутина, Я. Данек, А.Р. Рымханова // Вестн. Караганд. ун-та. Сер. Педагогика. — 2017. — № 4(88). - C. 17-24.

7 Сайт Bagdar.kz! [Электронный ресурс]. — Режим доступа: https://bagdar.kz/

\section{Е.И. Барабанова, Ғ.З. Әділғазинов, А.Т. Жакупов}

\section{Инклюзивті колледждегі ерекше білім алу қажеттіліктері бар студенттердің кәсіби даму ерекшеліктері}

\begin{abstract}
Мақалада Шығыс Қазақстан облысындағы екі кәсіптік-техникалық инклюзивті колледж студенттерінің біліктілігін арттырудың салыстырмалы зерттеу нәтижелері келтірілген. Зерттеуге арнайы білімге мұқтаж 50 студент қатысты. Зерттеудің әдіснамалық негізі кәсіптік бағдарлау Бағдар.kz сайтында ұсынылған қазақстандық ғалымдардың кәсіби-бағытталған веб-сайттарының авторлық психодиагностикалық туындылары болды. Мәліметтерді талдау негізінде студенттердің бейімділігі мен қызығушылығы мамандық бойынша оқытудың нақты таңдау мен сәйкес келмейтіндігі туралы қорытынды жасалынды. 12 кәсіби бағыт және 36 мамандық бойынша ЕБАК бар студенттерді іріктеу нәтижелері қарастырылды. Кәсіби бағдар таңдаудағы жетекші мотивтер мен қажеттіліктер анықталды, олар ЕБАК бар ТКББ студенттердің мамандықтарын таңдаумен байланысты. ЕБАК бар инклюзивті колледждерінің студенттері үшін жұмыстың тартымды түрлері, еңбек нысандары және еңбек құралдары белгіленді. Зерттеудің практикалық маңыздылығы колледжде кәсіби даму кезеңінде ерекше білім алу қажеттіліктері бар студенттердің кәсіби ниеттері мен мүдделерін егжей-тегжейлі зерделеуден тұрады. Зерттеудің практикалық құндылығы оның кәсіптік білім беруді дараландырумен
\end{abstract}


байланысты мәселелерді шешуге және ЕБАК бар әр студентке кәсіби шеберлігін шындауда қиындықтарға тап болған кезінде көмек беруге бағытталғандығымен анықталады.

Кілт сөздер: инклюзивті білім беру, мүмкіндігі шектеулі адамдар, инклюзия, инклюзивті оқыту, колледж.

\author{
Е.И. Барабанова, Г.З. Адилгазинов, А.Т. Жакупов
}

\title{
Особенности профессионального становления студентов с особыми образовательными потребностями в условиях инклюзивного колледжа
}

\begin{abstract}
В статье представлены результаты проведенного сравнительного исследования профессионального становления студентов двух профессионально-технических инклюзивных колледжей ВосточноКазахстанской области. В исследовании приняли участие 50 студентов с особыми образовательными потребностями (далее ООП). Методическую основу исследования составили авторские психодиагностические разработки профориентационных сайтов казахстанских ученых, представленные на профориентационном сайте Bagdar.kz. На основе анализа данных сделаны выводы о несоответствии склонностей и интересов студентов реальному выбору обучения по специальности. Были рассмотрены результаты выбора студентов с ООП по 12 профессиональным отраслям и 36 специальностям. Определены ведущие мотивы и потребности в выборе профессиональной направленности, которые соотнесены с выбором специальности студентов с ООП из ТиПО. Выделены привлекательные виды деятельности, объекты труда и предпочитаемые средства труда у студентов с ООП инклюзивных колледжей. Практическая значимость исследования заключалась в детальном рассмотрении профессиональных намерений и интересов студентов с особыми образовательными потребностями на этапе профессионального становления в условиях колледжа. Практическая ценность исследования определена тем, что оно ориентировано на решение проблем, связанных с индивидуализацией профессиональной подготовки и оказанием помощи каждому студенту с ООП, который нуждается в ней и испытывает трудности в ходе профессионализации.
\end{abstract}

Ключевые слова: инклюзивное образование, люди с ограниченными возможностями, инклюзия, инклюзивное обучение, колледж.

\section{References}

1 Hosudarstvennaia prohramma razvitiia obrazovaniia Respubliki Kazakhstan na 2011-2020 hody, utverzhdennaia Ukazom Prezidenta Respubliki Kazakhstan ot 07.12.2010 h. No. 1118 [The State Program for the Development of Education of the Republic of Kazakhstan for 2011-2020, approved by Decree of the President of the Republic of Kazakhstan dated 2010.12.07 No. 1118]. (2010). Kazakhstanskaia pravda - Kazakhstanskaya pravda, No. 1 53-154, 10-12 [in Russian].

2 Ukaz Prezidenta Respubliki Kazakhstan ot 1 marta 2016 hoda No. 205 «Ob utverzhdenii Hosudarstvennoi prohrammy razvitiia obrazovania i nauki na 2019-2019 hody» [Decree of the President of the Republic of Kazakhstan dated March 1, 2016 No. 205 «On approval of the state program for the development of education and science of the Republic of Kazakhstan for 2016 2019»]. adilet.zan.kz. Retrieved from http://adilet.zan.kz [in Russian].

3 Eralieva, H.S. (2016). Vnedrenie inkliuzivnoho obrazovaniia v Kazakhstane [Introduction of inclusive education in Kazakhstan]. Innovative pedagogical technology: IV Mezhdunarodnaia nauchnaiia konfeentsiia (mai 2016 h.) - IV international scientific conference. (pp. 26-28). Kazan: Buk [in Russian].

4 Sardarova, Zh.I., \& Zhumasheva, N.S. (2017). Inkliuzivnoe i intehrirovannoe obuchenie v Respublike Kazakhstan [Inclusive and integrated education in the Republic of Kazakhstan]. Nauchno-metodicheskii elektronnyi zhurnal «Kontsept»-Scientificmethodological electronic journal «Concept», Vol. 35, 113-116 [in Russian].

5 Sakaeva, A.N., \& Oleksjuk, Z.Ja. (2016). Hotovnost pedahohov k professionalnoi deiatelnosti v usloviiakh inkliuzivnoho obrazovaniia [Readiness of teachers for professional activity in the conditions of inclusive education]. Vestnik Karahandinskoho universiteta. Seriia Pedahohika - Vestnik of Karaganda University. Series Educationa lscience, No. 1(81), 32-38 [in Russian].

6 Shkutina, L.A., Danek, Ja., \& Rymhanova, A.R. (2017). Otdelnye aspekty otnosheniia uchitelei k vnedreniiu inkliuzivnoho obrazovaniia v obshcheobrazovatelnye shkoly [Individual aspects of the attitude of teachers to the introduction of inclusive education in general academic school]. Vestnik Karahandinskoho universiteta. Seriia Pedahohika - Vestnik of Karaganda University. Series Educational science, No. 4(88), 17-24 [in Russian].

7 Sait Bahdar.kz! [Website Bagdar.kz!]. bagdar.kz/3. Retrieved from https://bagdar.kz/ 